\title{
Canine Tracheal Epithelial Cells Express the Type 1 Insulin-like Growth Factor Receptor and Proliferate in Response to Insulin-like Growth Factor I
}

\author{
George Z. Retsch-Bogart, Alan D. Stiles, Billie M. Moats-Staats, Michael R. Van Scott, \\ Richard C. Boucher, and A. Joseph D'Ercole \\ Departments of Pediatrics and Medicine, University of North Carolina at Chapel Hill, Chapel Hill, North Carolina
}

\begin{abstract}
Disaggregated airway epithelial cells replicate in serum-free media containing supraphysiologic concentrations of insulin. To examine the hypothesis that the type 1 insulin-like growth factor (IGF) receptor mediates the mitogenic action of insulin on these cells, we studied the mitogenic effects of IGF-I and insulin, and the expression of type 1 IGF receptors in primary cultures of adult canine tracheal epithelial cells. Isolated tracheal epithelial cells were grown in varying concentrations of IGF-I or insulin in Harn's F12 medium supplemented with transferrin, cholera toxin, and endothelial cell growth supplement. Both IGF-I and insulin increased DNA synthesis (measured as [ $\left.{ }^{3} \mathrm{H}\right]$ thymidine incorporation into DNA) and cell number in a concentration-dependent fashion, but IGF-I was at least 20 to 60 times more potent than insulin in its mitogenic effects. No additive or synergistic effect was observed with the simultaneous addition of IGF-I and insulin in maximally effective doses. A monoclonal antibody directed against the type 1 IGF receptor $(\alpha$ IR3) blocked the mitogenic activity of both IGF-I and insulin. Affinity labeling of type 1 IGF receptors by covalent cross-linking with disuccinimidyl suberate demonstrated the tracheal epithelial cell IGF-I binding moiety to have a relative molecular weight of $130,000 \mathrm{D}$. Binding of [125]]IGF-I to this protein was inhibited by low concentrations of IGF-I, relative to insulin, and by $\alpha$ IR3. An 11-kb transcript characteristic of mRNA for the type 1 IGF receptor was recognized in poly $\left(\mathrm{A}^{+}\right)$RNA derived from cultured canine tracheal epithelial cells. These data demonstrate, by functional, biochemical, and molecular methods, that cultured canine tracheal epithelial cells express type 1 IGF receptors which mediate their mitogenic response to IGF-I or supraphysiologic concentrations of insulin. These results also raise the possibility that IGF-I may have an important role in growth and differentiation of large airways epithelium.
\end{abstract}

The factors controlling airway epithelial growth and differentiation during development and repopulation after injury are not defined. Peptide growth factors have been implicated in these processes (1). Evidence of a role for insulin-like growth factor I (IGF-I) comes from the findings that it is synthesized in the lung (2) and that type 1 IGF cell membrane receptors have been demonstrated in lung tissue (3).

Supraphysiologic concentrations of insulin have been used

Key Words: insulin-like growth factors, IGF-I, insulin, type 1 insulin-like growth factor receptor, canine tracheal epithelium

(Received in original form August 28, 1989 and in revised form April 4, 1990)

Address correspondence to: George Z. Retsch-Bogart, M.D., Department of Pediatrics, CB\# 7220, University of North Carolina at Chapel Hill, Chapel Hill, NC 27599-7220.

Abbreviations: bovine serum albumin, BSA; cholera toxin, CT; endothelial cell growth supplement, ECGS; fetal bovine serum, FBS; insulin-like growth factor I, IGF-I; transferrin, TF.

Am. J. Respir. Cell Mol. Biol. Vol. 3. pp. 227-234, 1990 to support the growth of a wide variety of epithelial cells, including tracheal epithelium in vitro (4). In cells other than pulmonary epithelia, high concentrations of insulin can interact with the type 1 insulin-like growth factor receptor to stimulate mitosis (5-7). We postulated, therefore, that in airway epithelia, insulin's effect or cell proliferation is also mediated through the type 1 IGF receptor and that IGF-I is a more potent mitogen for epithelial cells than insulin by virtue of preferential binding to its high-affinity receptor. To examine these questions, we determined the mitogenic effects of IGF-I using cultured canine tracheal epithelial cells in defined, serum-free media, and examined the expression of the type 1 IGF receptor by tracheal epithelial cells.

\section{Materials and Méthods \\ Materials}

Cell culture-grade insulin, transferrin (TF), endothelial cell growth supplement (ECGS), and cholera toxin (CT) were obtained from Collaborative Research (Lexington, MA). Ham's F12 and Eagle's minimum essential media (MEM) 
were from GIBCO (Grand Island, NY). Fetal bovine serum (FBS) was obtained from Hyclone Laboratories (Logan, UT). Protease XIV, trypsin, deoxyribonuclease (DNAse), monoclonal anti-human myoglobin antibody, and bovine serum albumin (BSA), fraction V (lot No. 88f-0071, IGF-Ifree) were purchased from Sigma Chemical Co. (St. Louis, MO). Disuccinimidyl suberate was from Pierce (Rockford, IL). Recombinant [Thr $\left.r^{59}\right]$ IGF-I was from Amgen Biologicals (Thousand Oaks, CA). Guanidine thiocyanate was purchased from Fluka (Ronkonkoma, NY), and cesium chloride from Gallard-Schlesinger (Carle Place, NY). [Methyl${ }^{3} \mathrm{H}$ ]thymidine (sp act, $91 \mathrm{Ci} / \mathrm{mmol}$ ), $\mathrm{Na}{ }^{125}$, and $\left[\alpha-{ }^{32} \mathrm{P}\right] \mathrm{UTP}$ were obtained from Amersham (Arlington Heights, IL). Monoclonal antibody against the type 1 IGF receptor ( $\alpha$ IR3) was a gift from J. J. Van Wyk and S. Jacobs (8). [ $\left.{ }^{125} I\right]-$ labeled IGF-I was prepared from recombinant IGF-I, purified by immunoaffinity chromatography, and labeled by the chloramine $T$ method (9). A human cDNA for the type 1 IGF receptor was obtained from American Type Culture Collection (No. 59294; Rockville, MD).

\section{Isolation of Cells}

Mongrel dogs were killed by an i.v. injection of pentobarbital $(125 \mathrm{mg} / \mathrm{kg})$, tracheas removed, and tracheal epithelial cells isolated as described by Wu and Smith (10). Briefly, connective tissue was removed and the tracheal segments were rinsed in MEM and treated with $0.1 \%$ protease XIV and $0.01 \%$ DNAse in MEM for $16 \mathrm{~h}$ at $4^{\circ} \mathrm{C}$. FBS $(10 \%)$ was then added, the mixture was agitated vigorously, and the disaggregated cells were filtered through Nitex mesh. The cells were centrifuged at $500 \times g$ for $10 \mathrm{~min}$, the pellet washed with MEM and $10 \%$ FBS, resuspended, and centrifuged again. The final pellet was resuspended in 5\% FBS and Ham's F12 medium (F12) supplemented with penicillin (50 $\mathrm{U} / \mathrm{ml})$, streptomycin $(50 \mathrm{U} / \mathrm{ml})$, and gentamicin $(50 \mu \mathrm{g} / \mathrm{ml})$. Cell viability was determined by exclusion of trypan blue, and was consistently $>90 \%$. Tracheal epithelial cells isolated by this technique are virtually free of fibroblast contamination as judged by morphology and antikeratin immunostaining (10). Serum-free conditions used after cell attachment to plastic substrate do not support fibroblast survival (11).

\section{Culture Conditions}

The disaggregated cells suspended in F12 with 5\% FBS were plated in 24-well (16-mm-diam well) tissue culture plates (Costar, Cambridge, MA) at a density of $2 \times 10^{5}$ cells $/ \mathrm{cm}^{2}$. After $24 \mathrm{~h}$, the unattached cells were removed and the culture medium was replenished with F12 supplemented with TF (5 $\mu \mathrm{g} / \mathrm{ml}), \mathrm{CT}(0.01 \mu \mathrm{g} / \mathrm{ml})$, ECGS $(7.5 \mu \mathrm{g} / \mathrm{ml})$, and various concentrations of insulin or IGF-I. Every other day, cells were washed with F12 and fresh medium was added. All experiments were performed using subconfluent monolayer cultures, as judged by phase-contrast microscopy. Cell cultures were maintained at $37^{\circ} \mathrm{C}$ in $95 \%$ humidity and $5 \% \mathrm{CO}_{2}$.

\section{Growth Properties of Canine Tracheal Epithelial Cells}

Cells were grown on plastic culture plates in F12 with TF, CT, and ECGS (control medium), or control medium supplemented with insulin ( $860 \mathrm{nM}$ or $10 \mu \mathrm{g} / \mathrm{ml}$ ) or IGF-I (13
$\mathrm{nM}$ or $100 \mathrm{ng} / \mathrm{ml}$ ). Each day for $5 \mathrm{~d}$, cells were removed from four wells by trypsinization $(0.1 \%$ trypsin and $1 \mathrm{mM}$ EDTA) and cell number was determined in quadruplicate by electronic cell counting (Model $Z_{\mathrm{Bl}}$; Coulter, Hialeah, FL). The cell doubling time was calculated by the method of Chen and Chen (12).

To determine the concentration relationship of the growth response to IGF-I and insulin, freshly isolated tracheal epithelial cells were plated in plastic multiwell plates and allowed to attach over a $24-\mathrm{h}$ period. The media was then changed to provide F1 2 with TF, CT, and ECGS with multiple concentrations of insulin or IGF-I. On the fifth day in culture, $1 \mu \mathrm{Ci}$ of [methyl- ${ }^{3} \mathrm{H}$ ] thymidine was added to the media. Twenty-four hours later, the cells were removed by trypsinization, and cell number and [methyl- $\left.{ }^{-} \mathrm{H}\right]$ thymidine incorporation into DNA were determined. Cellular DNA was precipitated in cold perchloric acid-methanol, the precipitant recovered by centrifugation, and radioactivity of the pellet measured (13).

The effect of the simultaneous addition of insulin and IGF-I to canine tracheal epithelial cells was determined by growing cells in control medium and $1.7 \mu \mathrm{M}$ insulin with multiple concentrations of IGF-I. [Methyl- ${ }^{3} \mathrm{H}$ ] thymidine $(1 \mu \mathrm{Ci}$ per well) was added $16 \mathrm{~h}$ before harvesting on the sixth day. Cell number per well and tritiated thymidine incorporation into DNA were determined for each culture condition. The same procedure was followed for tracheal epithelial cells grown in control medium and $6.5 \mathrm{nM}$ IGF-I with multiple concentrations of insulin.

\section{Inhibition of Type 1 IGF Receptor-ligand Binding}

Canine tracheal epithelial cells were isolated as described above, but after protease/DNAse treatment, $2.5 \%$ BSA was added to the solution in place of $10 \%$ FBS to prevent possible interactions of serum components with cell surface receptors and antibody. The disaggregated cells were suspended and plated in F12 with TF, CT, and ECGS (control medium). After cell attachment, the cells were washed, and monoclonal antibody directed against the IGF receptor (8) was added to one half of the wells at a concentration of $550 \mathrm{nM}(100$ $\mu \mathrm{g} / \mathrm{ml})$. Four hours later, additional media, control medium, or control with either IGF-I $(13 \mathrm{nM})$ or insulin $(170 \mathrm{nM})$ was added to paired groups of wells. After a 4-d incubation period during which the culture media was not changed, the cells were removed and cell number was determined by electronic cell counting. Exactly the same procedure was followed using a monoclonal antibody directed against human myoglobin (at the same molar concentration) to serve as an isotypic control antibody.

\section{Affinity Cross-linking Analysis}

Previously described methods $(14,15)$ were used with the following modifications. Canine tracheal epithelial cells plated at a density of $2 \times 10^{5}$ cells $/ \mathrm{cm}^{2}$ on $60-\mathrm{mm}$ plastic dishes were incubated for $18 \mathrm{~h}$ in F12 with 5\% FBS and then $3 \mathrm{~d}$ with F12 plus control medium with $1.7 \mu \mathrm{M}$ insulin, as described above. Media was then aspirated and the cell monolayer washed three times with $3 \mathrm{ml}$ Hepes binding buffer ( 20 $\mathrm{mM}$ Hepes, pH 7.4, $120 \mathrm{mM} \mathrm{NaCl}, 5 \mathrm{mM} \mathrm{KCl}, 1.2 \mathrm{mM}$ $\mathrm{MgSO}_{4}, 10 \mathrm{mM} \mathrm{NaHCO}, 1.3 \mathrm{mM} \mathrm{CaCl}$, and $1.2 \mathrm{mM}$ 
$\mathrm{KH}_{2} \mathrm{PO}_{4}$ ) with $1 \%$ BSA (fraction V, IGF-I free; Sigma). Cells were then incubated with ['25I]-labeled IGF-I $\left(6 \times 10^{5}\right.$ cpm/dish) in Hepes binding buffer (with $1 \%$ BSA) with or without various concentrations of unlabeled IGF-I, insulin, or monoclonal antibody at $8^{\circ} \mathrm{C}$ for $20 \mathrm{~h}$. After incubation, the media was aspirated and cells were washed with $3 \mathrm{ml}$ ice-cold Hepes buffer without BSA. Disuccinimidyl suberate $(0.1 \mathrm{mM})$ in Hepes binding buffer without BSA was added for $15 \mathrm{~min}$ at room temperature. The reaction was quenched by adding

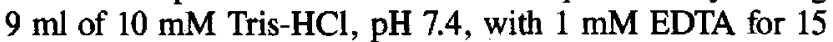
$\min$. The solution was aspirated and the cells were solubilized in $200 \mu \mathrm{l}$ of $2 \% \mathrm{SDS}, 0.05 \mathrm{M}$ Tris- $\mathrm{HCl}$, and $0.1 \mathrm{M}$ DTT. The cell lysates were removed by scraping with a rubber policeman and transferred to microfuge tubes. The samples were concentrated by evaporation (Savant, Farmingdale, NY) for $3 \mathrm{~h}$ to one-half their original volume and then boiled for 5 min. Sample proteins and $\left[{ }^{14} \mathrm{C}\right]$-labeled molecular weight standards (myosin, $M_{\mathrm{r}}=200,000$; phosphorylase $\mathrm{b}, M_{\mathrm{r}}=$ 100,000; BSA, $M_{\mathrm{r}}=69,000$; ovalbumin, $M_{\mathrm{r}}=46,000$; and carbonic anhydrase, $\left.M_{\mathrm{r}}=30,000\right)$ were separated using $10 \%$ SDS-PAGE (16). The gel was fixed in $10 \%$ acetic acid and $30 \%$ methanol, washed, dried, and exposed to Kodak AR5 film in the presence of Dupont Cronex Lightning Plus intensifying screens at $-70^{\circ} \mathrm{C}$.

\section{Northern Hybridization Analysis}

IGF-I receptor cDNA corresponding to a 706-bp segment of the $\alpha$ subunit was cloned into the EcoR1 site of $\mathrm{pBS}^{+}$(Stratagene, La Jolla, CA) and a [32P]-labeled antisense riboprobe was in vitro transcribed using T7 RNA polymerase and $[\alpha-$ ${ }^{32}$ P]UTP (17). Subconfluent primary cultures of canine tracheal epithelial cells, grown for $6 \mathrm{~d}$ after plating as described above in plastic T-150 flasks in control medium with $1.7 \mu \mathrm{M}$ insulin, were solubilized with $4 \mathrm{M}$ guanidine thiocyanate directly in culture flasks. Total cellular RNA was extracted by centrifugation through a $5.7 \mathrm{M} \mathrm{CsCl}$ cushion (18) and poly $\left(A^{+}\right)$RNA isolated using oligo (dT) cellulose (19). Samples of poly $\left(\mathrm{A}^{+}\right) \mathrm{RNA}$ were denatured in glyoxal and dimethyl sulfoxide at $50^{\circ} \mathrm{C}$ and size-fractioned by electrophoresis in $1 \%$ agarose gels. After capillary transfer to nylon membranes (Gene Screen; New England Nuclear, Boston, MA) (20); baking at $80^{\circ} \mathrm{C}$, and UV cross-linking, the membrane was prehybridized with buffer $(6 \times \mathrm{SSC}, 50 \mathrm{mM}$ Tris- $\mathrm{HCl}$, $\mathrm{pH} 7.0,10 \times$ Denhardt's reagent, and $50 \%$ formamide). Hybridization to a $\left.{ }^{32} \mathrm{P}\right]$-labeled riboprobe was performed for $16 \mathrm{~h}$ at $65^{\circ} \mathrm{C}$. After standard posthybridization washes in 50 $\mathrm{mM} \mathrm{NaCl}, 20 \mathrm{mM} \mathrm{NaHPO}, 1 \mathrm{mM}$ EDTA, and 1\% SDS at $55^{\circ} \mathrm{C}$, the membrane was air-dried and exposed to Kodak AR5 film with intensifying screens at $-70^{\circ} \mathrm{C}$ for $16 \mathrm{~h}(21)$.

\section{Statistics}

Studies of tracheal epithelial cell growth and inhibition of type 1 receptor binding were performed in quadruplicate for each experiment. Analysis of variance with Tukey's method of multiple comparison was used to compare data from experiments with more than two samples. A $P$ value $<0.05$ was used for all tests.

\section{Results}

The canine tracheal epithelial cells studied are polygonal and

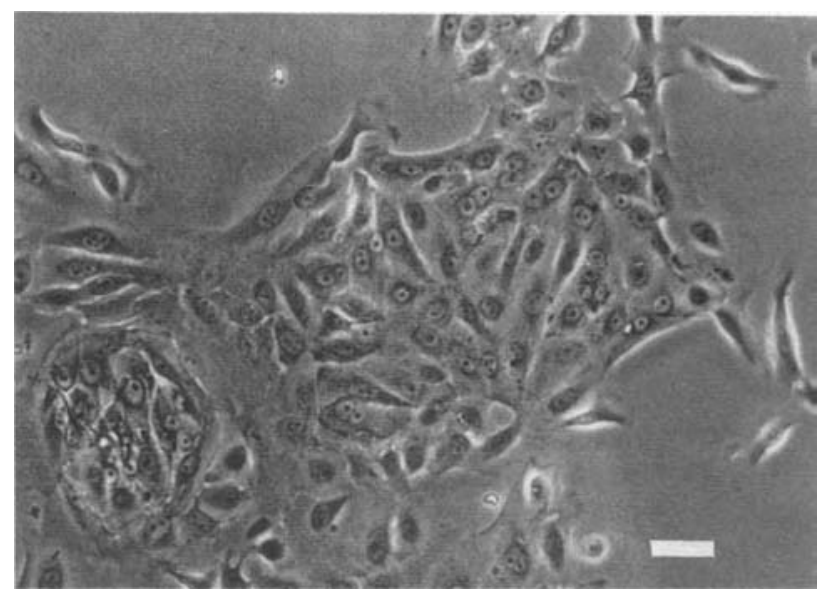

Figure 1. Phase-contrast microscopy of canine tracheal epithelial cells on plastic substrate. Bar $=\mathbf{5 0} \mu \mathrm{m}$.

have the morphologic characteristics of epithelial cells. Figure 1 is a phase-contrast photomicrograph of these cells under subconfluent conditions. Canine tracheal epithelial cells cultured in Ham's F12 medium supplemented with TF, CT, and ECGS did not proliferate, whereas with the addition of either insulin $(860 \mathrm{nM})$ or IGF-I $(13 \mathrm{nM})$, their cell doubling times were $109 \pm 31$ and $106 \pm 41 \mathrm{~h}$ (mean $\pm \mathrm{SD} ; n=$ 4 or 5), respectively (Figure 2). Both IGF-I and insulin stimulated a concentration-dependent proliferation of tracheal epithelial cells (Figure 3). Each peptide produced an

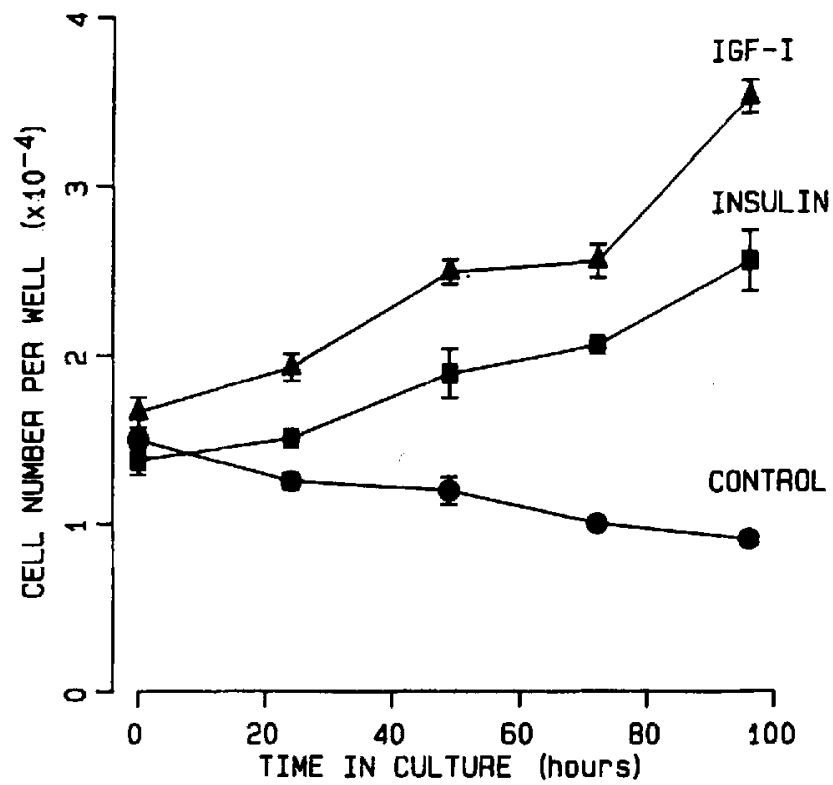

Figure 2. Growth of canine tracheal epithelial cells on plastic substrate. Cells $\left(2 \times 10^{3}\right.$ cells $\left./ \mathrm{cm}^{2}\right)$ were plated in 24-well culture plates and maintained in Ham's F12 with TF, CT, and ECGS (control medium) (circles), control with $860 \mathrm{nM}$ insulin (squares), or control with $13 \mathrm{nM}$ IGF-I (triangles). Cell number per well was determined in quadruplicate. Mean \pm SEM are shown from a representative experiment. 

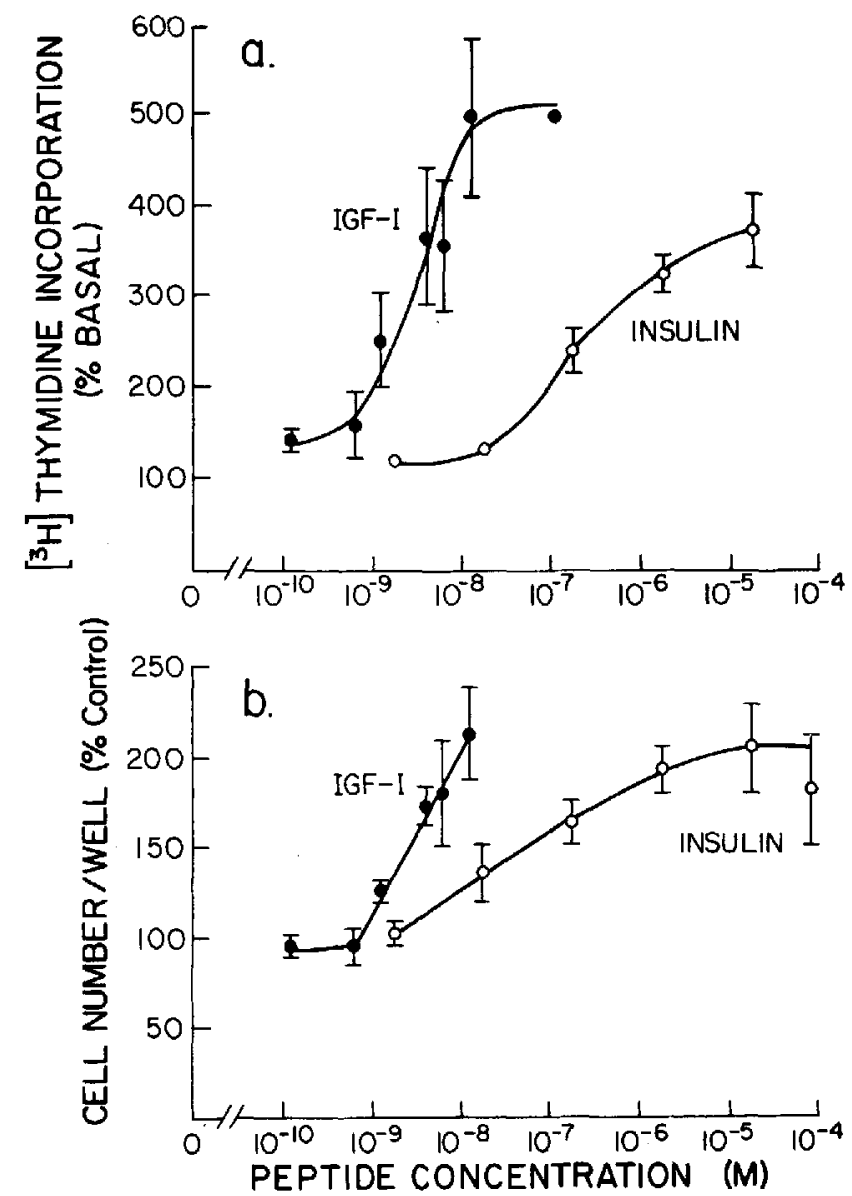

Figure 3. IGF-I and insulin stimulation of DNA synthesis and cell proliferation. Canine tracheal epithelial cells were initially plated in Ham's Fl 2 with 5\% FBS for $24 \mathrm{~h}$, and then maintained for $6 \mathrm{~d}$ in control medium and multiple concentrations of either IGF-I (closed circles) or insulin (open circles) with media changes every other day. Data points represent mean \pm SEM of experiments using tracheal epithelial cells from nine animals (each point represents two to seven experiments, each performed in quadruplicate). (a.) [Methyl- ${ }^{3} \mathrm{H}$ ] thymidine incorporation into DNA. After $5 \mathrm{~d}$ of growth, $1 \mu \mathrm{Ci} / \mathrm{ml}$ [methyl- ${ }^{3} \mathrm{H}$ ]thymidine was added to each well and incubated another $16 \mathrm{~h}$. Methanol-perchloric acid-precipitated material was collected and scintillation counting performed. (b.) Tracheal epithelial cells were treated as described above. After a 6-d incubation, cells were harvested and counted using a Coulter counter.

increase in DNA synthesis and cell number, but IGF-I was more potent than insulin. The concentration of IGF-I required to affect proliferation was 20-fold lower than that of insulin when half-maximal stimulation was calculated $(3 \mathrm{nM}$ for IGF-I and $60 \mathrm{nM}$ for insulin). Similar differences (60fold) were observed when thymidine incorporation was used to calculate half-maximal stimulatory effects ( $3 \mathrm{nM}$ for IGF-I and $180 \mathrm{nM}$ for insulin). No additional increase in thymidine incorporation into DNA was seen with $100 \mathrm{nM}$ IGF-I in a single experiment. When the minimum dose required for maximal proliferation was used as a measure of potency (10 $\mathrm{nM}$ IGF-I versus $10 \mu \mathrm{M}$ insulin), IGF-I was approximately 1,000 times more potent than insulin.
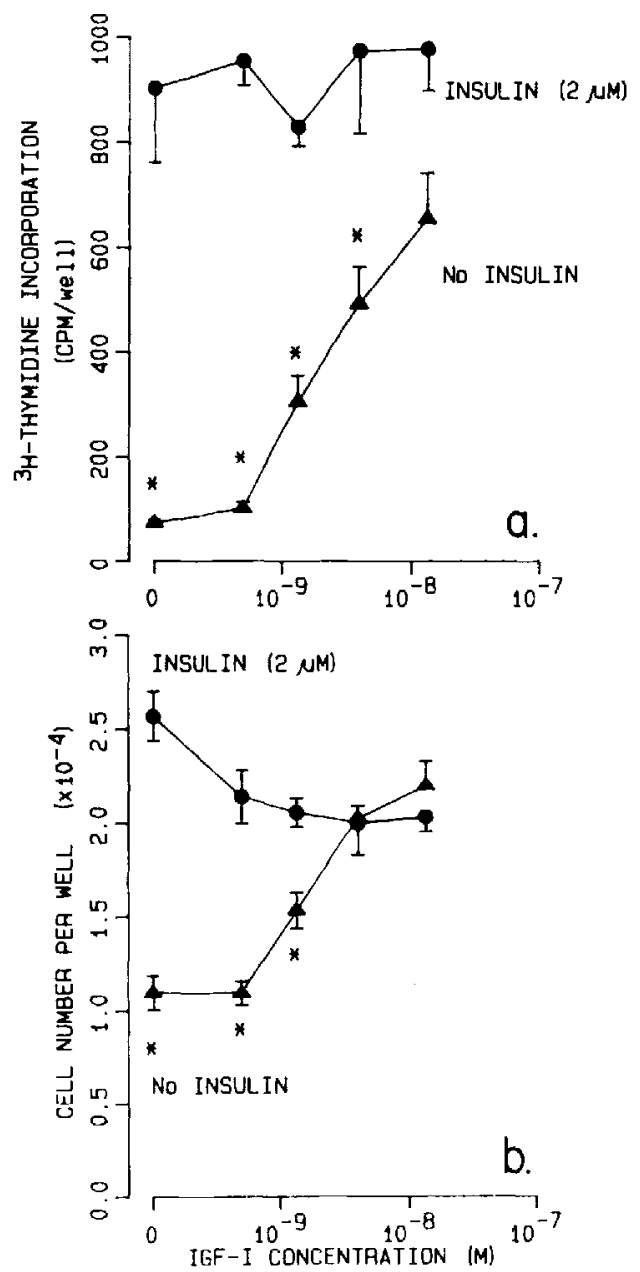

Figure 4. Additive effects of IGF-I and insulin on cell proliferation and DNA synthesis in canine tracheal epithelial cells. Each point is expressed as the mean \pm SEM from quadruplicate wells in a representative experiment from the same animal. Asterisks indicate significant differences $(P<0.05)$ between cells incubated in the presence and absence of insulin at the same IGF-I concentrations. (a.) Cells initially plated in F12 with $5 \%$ FBS for $24 \mathrm{~h}$ were maintained in Ham's F12 plus TF, CT, ECGS, and either IGF-I and insulin $(1.7 \mu \mathrm{M})$ (circles) or IGF-I alone (triangles). After $5 \mathrm{~d}$ of growth in defined medium with media changes every other day, $1 \mu \mathrm{Ci} / \mathrm{ml}$ [methyl- ${ }^{3} \mathrm{H}$ ] thymidine was added to each well for a 16-h incubation. Methanol-perchloric acid-precipitated material was collected and scintillation counting performed. (b.) Cells were treated as described above. At the conclusion of the growth period, cell number was determined using a Coulter counter. No differences were seen among cells incubated with $1.7 \mu \mathrm{M}$ insulin and multiple IGF-I concentrations.

To determine if the effects of IGF-I's and insulin were additive or synergistic, increasing concentrations of IGF-I were added to a concentration of insulin that stimulated mitosis. As illustrated in Figure 4, no further increase in cell proliferation or DNA synthesis was observed when $13 \mathrm{nM}$ IGF-I was combined with $1.7 \mu \mathrm{M}$ insulin in the culture medium. Similar results were obtained when increasing doses of insulin were added to a mitogenic concentration of IGF-I (Figure 5). These results suggest that both IGF-I and insulin act through a common mechanism. 

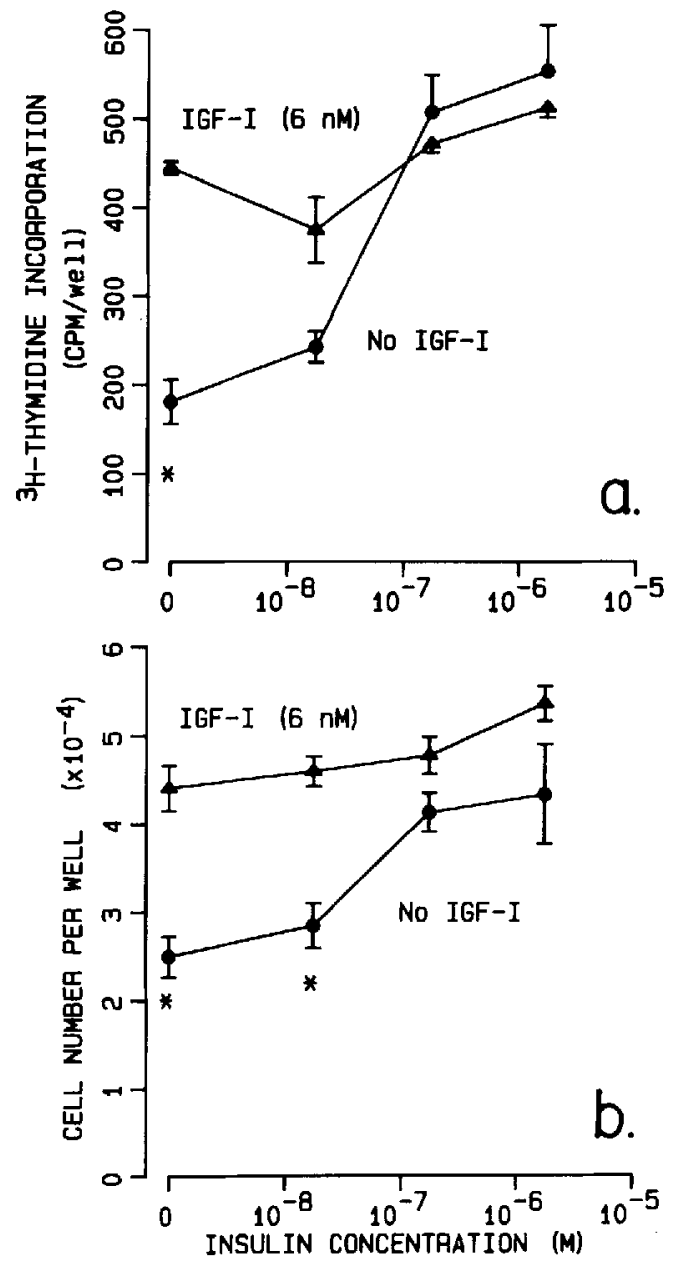

Figure 5. Additive effects of insulin and IGF-I on cell proliferation and DNA synthesis in canine tracheal epithelial cells. Each point is expressed as the mean \pm SEM from quadruplicate wells in a representative experiment from the same animal. Asterisks indicate significant differences $(P<0.05)$ between cells incubated in the presence and absence of IGF-I at the same insulin concentrations. (a.) Tracheal epithelial cells were initially plated in F12 with $5 \%$ FBS for $24 \mathrm{~h}$ and then maintained in F12 plus TF, CT, ECGS, and either insulin and IGF-I (6.5 nM) (triangles) or insulin alone (circles). After $5 \mathrm{~d}$ of growth in defined medium, $1 \mu \mathrm{Ci} / \mathrm{ml}$ [methyl- ${ }^{3} \mathrm{H}$ ]thymidine was added to each well for a 16-h incubation. Methanolperchloric acid-precipitated material was collected and scintillation counting performed. (b.) Cells were treated as described above. At the end of the growth period, cell number was determined using a Coulter counter. No differences were seen among cells incubated with $6.5 \mathrm{nM}$ IGF-I and multiple insulin concentrations.

To investigate whether IGF-I's and insulin's mitogenic actions are mediated by binding to the type 1 IGF receptor, the stimulatory effects of each were studied in the presence of an antibody directed against this receptor. This antibody, $\alpha$ IR3, has been shown to inhibit binding of both IGF-I and insulin to the type 1 receptor $(5,6,8)$. To control for any possible nonspecific effects of antibody addition to canine tracheal epithelial cells, an isotypic antibody (to myoglobin) was studied in an identical fashion. Figure 6 compares cell growth in the presence of the isotypic control antibody and

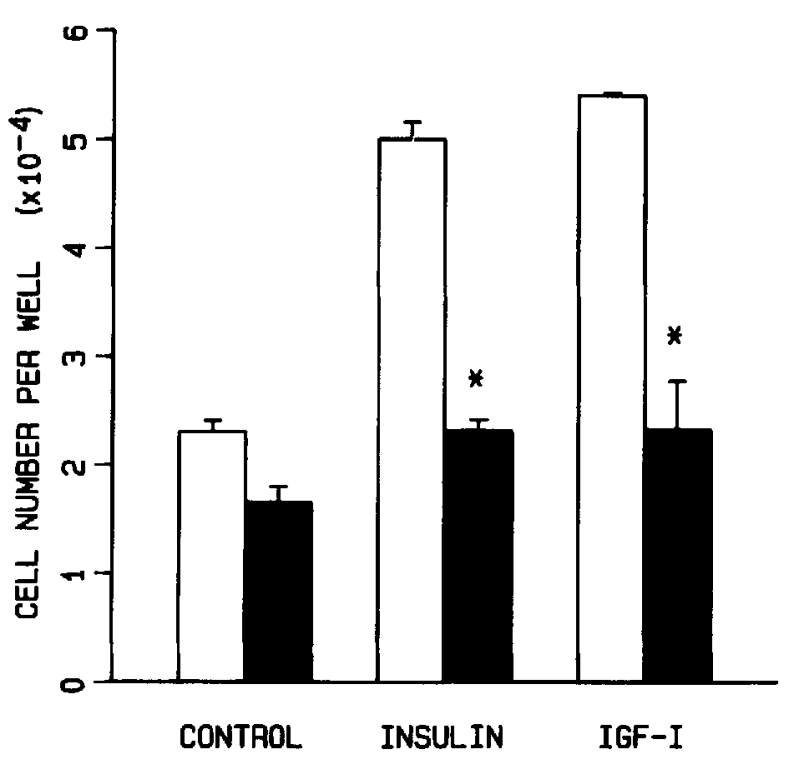

Figure 6. Inhibition of cell proliferation by monoclonal antibody to the type 1 IGF receptor. Cells were plated in 24-well plastic plates in serum-free medium (F12 with TF, CT, and ECGS). After a 1-d incubation for cell attachment, monoclonal antibody to the type 1 IGF receptor ( $\alpha$ IR3, $550 \mathrm{nM}$ ) or control antibody (antihuman myoglobin, $550 \mathrm{nM}$ ) was added to one-half of the wells. Four hours later, additional media containing F12 with TF, CT, and ECGS (control medium) or control with either IGF-I (13 nM) or insulin $(170 \mathrm{nM})$ was added to paired groups of wells. After 4 additional $\mathbf{d}$ of incubation, cell number was determined.

The effect of each antibody was studied in cells from two animals; therefore, the proliferative response of each to insulin and IGF-I was tested to determine if comparisons between the two cell preparations was valid. Cell number per well (expressed $\times 10^{-4}$; mean $\pm S D$ ) measured at the conclusion of the growth period for each condition was: control medium, $1.18 \pm 0.09$ and $2.21 \pm 0.83$ $(P=0.13)$; insulin $(170 \mathrm{nM}), 4.14 \pm 0.43$ and $4.69 \pm 0.68(P=$ $0.96)$; IGF-I $(13 \mathrm{nM}), 3.95 \pm 0.26$ and $4.50 \pm 0.33(P=0.88)$ for the isotypic antibody and $\alpha \mathrm{IR} 3$, respectively. Because there were no statistical differences between the two cell preparations, they are shown together in this graph. In the respective experiments, $\alpha$ IR3 inhibited both insulin-stimulated and IGF-I-stimulated proliferation compared to cells incubated without antibody $(P<0.001)$, while the isotypic antibody had no inhibitory effect on these parameters.

Results are expressed as the mean \pm SEM. The shaded bars represent cells grown in the presence of $\alpha \mathrm{IR} 3$ and open bars cells incubated with control antibody. Asterisks denote significant differences $(P<0.001)$ in cell number in the presence of antibody.

anti-IGF receptor antibody and either insulin or IGF-I, as well as in their absence. The proliferative response to IGF-I and insulin was inhibited by $\alpha$ IR 3 in each case despite the addition of sufficient concentrations of either IGF-I (13 nM) or insulin $(170 \mathrm{nM})$ to stimulate cell proliferation. The cellular proliferative response was not inhibited in the presence of the same concentration of isotypic control antibody.

To confirm that IGF-I and insulin were interacting with the type 1 IGF receptor, affinity labeling was performed by cross-linking [ ${ }^{125}$ I]IGF-I with its binding moiety in the presence of various concentrations of IGF-I or insulin and monoclonal antibodies. Under reducing conditions, [ $\left.{ }^{125} \mathrm{I}\right] \mathrm{IGF}-\mathrm{I}$ was 


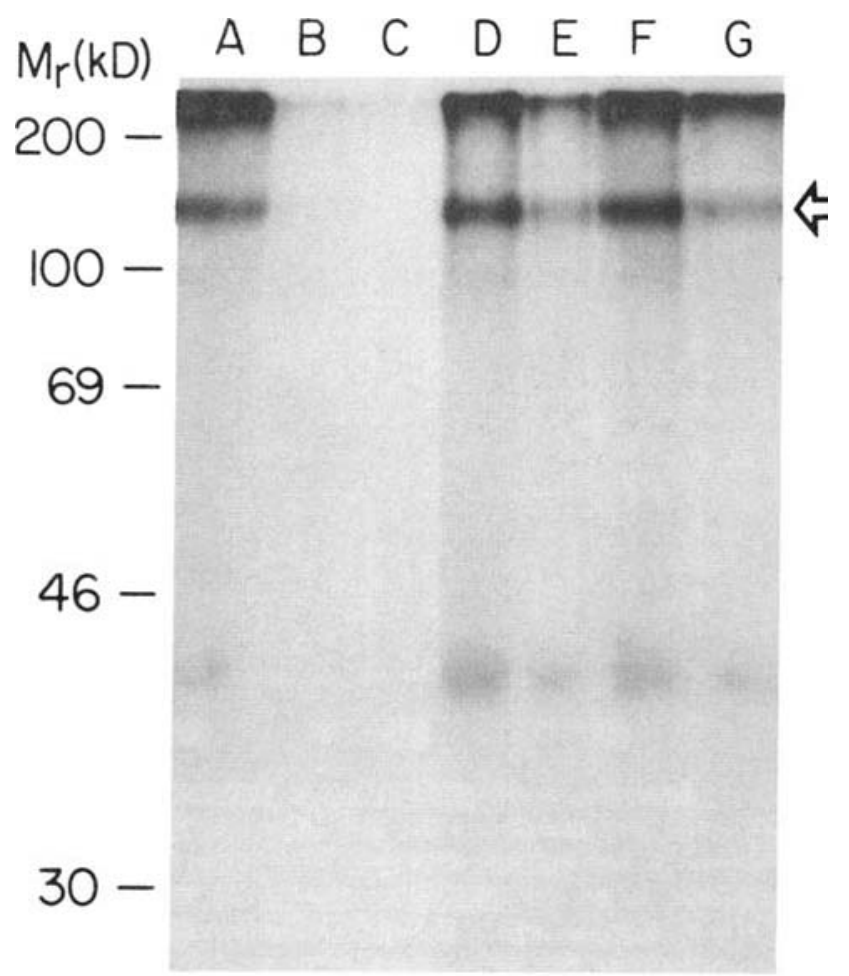

\section{Addition $0 \longmapsto$ IGF-I + INSULIN+ANTIBODY-

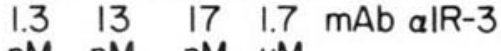 $\mathrm{nM} \quad \mathrm{nM} \quad \mathrm{nM} \quad \mu \mathrm{M}$}

Figure 7. Affinity cross-linking of IGF-I to canine tracheal epithelial cells. Tracheal epithelial cells were incubated for $18 \mathrm{~h}$ at $8^{\circ} \mathrm{C}$ with [ ${ }^{125}$ I] IGF-I in the absence (lane $A$ ) or the presence of unlabeled IGF-I, $1.3 \mathrm{nM}$ (lane $B$ ) or $13 \mathrm{nM}$ (lane $C$ ); unlabeled insulin, $17 \mathrm{nM}$ (lane $D$ ) or $1.7 \mu \mathrm{M}$ (lane $E$ ); or $550 \mathrm{nM}$ monoclonal antibody, control anti-myoglobin (lane $F$ ) or anti-type 1 IGF receptor/aIR3 (lane $G$ ). The arrow points to the [ $\left.{ }^{125} I\right] I G F-I$ affinitylabeled $\alpha$ subunit of the type 1 IGF receptor. The labeled moiety at about $40,000 \mathrm{D}$ is an affinity-labeled IGF binding protein. Affinity cross-linking was performed with $0.1 \mathrm{mM}$ disuccinimidyl suberate as described in MATERIALS AND METHods. Shown are autoradiographs of the radioligand-receptor complexes analyzed by PAGE under reducing conditions. The migration of molecular weight standards is indicated on the left.

bound to a protein of about $130,000 \mathrm{D}$ (Figure 7), a relative size that corresponds to the binding subunit of both the type 1 IGF receptor and the insulin receptor (22). Complete inhibition of labeled peptide binding occurred with as little as 1.3 nM IGF-I, whereas $1,700 \mathrm{nM}$ insulin was required to decrease the binding of [125]]IGF-I. This result confirms that the affinity-labeled moiety is the type 1 IGF receptor, rather than the insulin receptor, and is consistent with the known differences in receptor affinity for each peptide (23). Furthermore, the type 1 IGF receptor monoclonal antibody ( $\alpha$ IR3) competed with labeled peptide, whereas control antibody had no effect. This result demonstrates that the inhibitory effects of $\alpha \mathrm{IR} 3$ are mediated by its interaction with the type 1 IGF receptor.

To unequivocally confirm that canine tracheal epithelial cells express type 1 IGF receptors, Northern analysis of

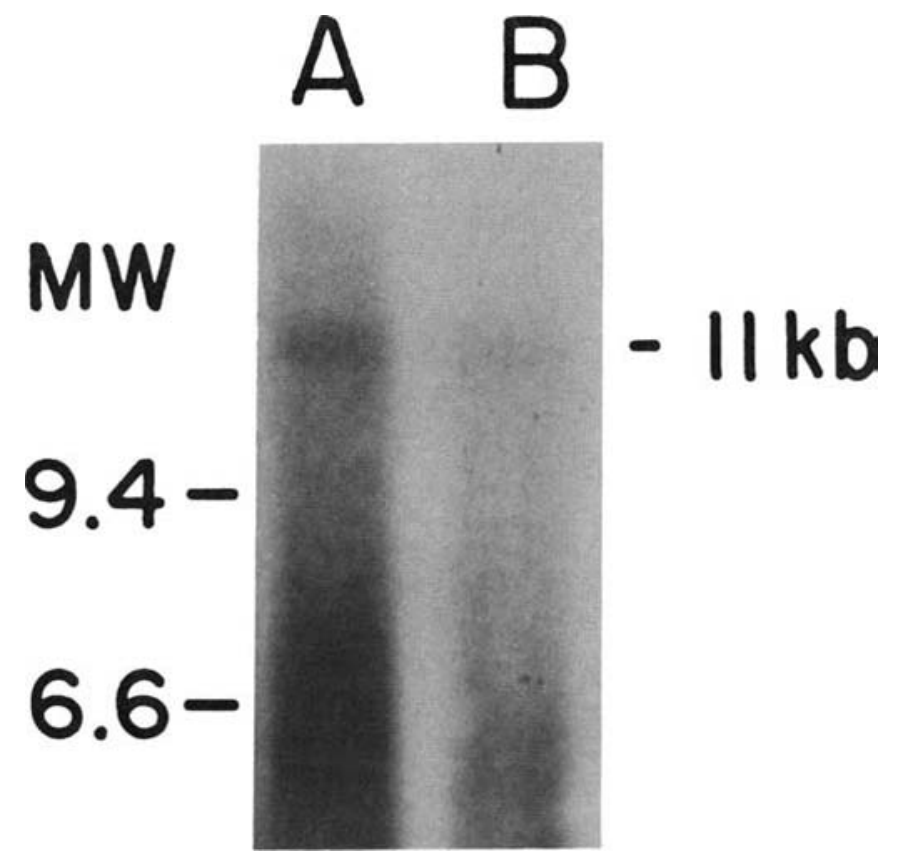

Figure 8. Northern hybridization of mRNA from canine tracheal epithelial celis with human type 1 IGF receptor riboprobe. An autoradiograph of poly $\left(\mathrm{A}^{+}\right) \mathrm{RNA}$ from primary cultures of canine tracheal epithelial cells hybridized with a $\left[{ }^{32} \mathrm{P}\right]$-labeled human type 1 IGF receptor riboprobe is shown. Lanes $\mathrm{A}$ and $\mathrm{B}$ contain $10 \mu \mathrm{g}$ and $5 \mu \mathrm{g}$, respectively, of poly $\left(\mathrm{A}^{+}\right)$RNA obtained from different animals. Cells had been isolated, plated, and grown for $5 \mathrm{~d}$ in F12 with TF, CT, ECGS, and $1.7 \mu \mathrm{M}$ insulin as described in MATERIALS AND MethoDs. The hybridizing band of $11 \mathrm{~kb}$ is indicated along with molecular weight standards.

poly $\left(\mathrm{A}^{+}\right) \mathrm{RNA}$ from primary cultures of canine tracheal epithelial cells was performed using a human IGF-I receptor riboprobe. This riboprobe recognized an mRNA of about 11 $\mathrm{kb}$ (Figure 8), a transcript of the same size reported by others in mRNA derived from mouse, rat (lung), and human tissue $(24,25)$. This result demonstrates that epithelial cells from canine trachea express a type 1 IGF receptor mRNA similar to those previously described, indicating significant sequence homology among species.

\section{Discussion}

We have demonstrated that canine tracheal epithelial cells in primary culture express type 1 IGF receptors and that these receptors mediate a mitogenic response. Expression of the type 1 IGF receptor was demonstrated by functional, biochemical, and molecular criteria. Namely, the response of tracheal epithelial cells to IGF-I and insulin is consistent with the relative affinities of each peptide to the type 1 IGF receptor (23); the canine tracheal epithelial cell IGF-I binding moiety has a relative molecular size of the binding subunit of the type 1 IGF receptor (about 140,000 D) (22), and binding of labeled IGF-I to this protein is inhibited by low concentrations of IGF-I, relative to those of insulin, and by a monoclonal antibody that is specific to this receptor; and, finally, an 11-kb transcript, characteristic of the mRNA for the type 1 IGF receptor in other species $(24,25)$, is recog- 
nized in poly $\left(\mathrm{A}^{+}\right)$RNA purified from canine tracheal epithelial cells.

We have also demonstrated that the proliferative response of canine tracheal epithelial cells to IGF-I and insulin is mediated by the type 1 IGF receptor. IGF-I stimulates DNA synthesis and cell proliferation in tracheal epithelial cells in concentrations 20 - to 60 -fold lower than those required for a similar response to insulin, a result consistent with the relative affinities of these peptides to the type 1 IGF receptor (23). Furthermore, a monoclonal antibody specific for the type 1 IGF receptor inhibits the response of canine tracheal epithelial cells to both IGF-I and insulin. These results also clarify why supraphysiologic concentrations of insulin stimulate cell proliferation in primary epithelial cell culture systems.

The selection of transferrin, endothelial cell growth supplement, and cholera toxin as supplements to the culture medium was determined, in part, by previous studies that suggested that these factors were necessary for optimal canine tracheal epithelial cell growth (26). Despite the mitogenic action of these supplements in other culture systems (4), a combination of these factors was not sufficient to allow tracheal cell proliferation without the addition of IGF-I or high concentrations of insulin.

Our results are consistent with an in vivo role for IGF-I in the stimulation of tracheal epithelial cell proliferation, because the nanomolar concentrations of IGF-I necessary to stimulate tracheal epithelial cell proliferation are likely to be within the physiologic range. Although lung tissue IGF-I concentrations are not known in humans or dogs, human serum concentrations are about $25 \mathrm{nM}(27)$, while canine serum concentrations average $10 \mathrm{nM}(28)$.

The tracheal epithelial cell types responsive to mitogenic stimulation are not known. Cells in this primary culture system are not morphologically differentiated but can be induced into ciliated and secretory cell types by manipulating substrate and culture media supplements $(11,26)$. Because basal cells and nonciliated cells have the shortest doubling times in vivo (29), they appear to be the best candidates for IGF-I responsiveness. Definitive demonstration of type 1 IGF receptors on specific epithelial cell types will require in situ hybridization and immunocytochemistry correlated with rigorous morphologic identification.

The lung is known to elaborate bioactive and immunoreactive IGF-I $(30,31)$ and to express type 1 IGF receptors (3). In the human fetus, a paracrine role for IGF-I has been postulated based on the findings that lung mesenchymal elements (septa, perivascular fibroblasts, and possibly interstitial cells) possess mRNA for IGF-I (32), while IGF-I identified by immunocytochemistry is localized to airway epithelium (33). Furthermore, Nakanishi and colleagues (34) recently showed that small-cell lung carcinoma cell lines produce an IGF-I precursor, proliferate in response to IGF-I, and demonstrate growth inhibition in the presence of anti-IGF receptor monoclonal antibody, consistent with an autocrine mode of action. Our study adds to the mounting evidence of a role for IGFs in the growth of lung epithelial cells by demonstrating that primary cultures of canine tracheal epithelial cells proliferate in response to IGF-I, an effect mediated by the type 1 IGF receptor. These results prompt us to speculate that IGF-I may be an important mitogen for the tracheal epithelium in early life and after injury.
Acknowledgments: We gratefully acknowledge advice and support from Dr. T. F. Boat in the completion of this work, and the gift of the monoclonal antibody $\alpha I R 3$ from Drs. J. J. Van Wyk and S. Jacobs. This work was supported by Grants HL38902, HL 34322, HD08299, and Training Grant HL.07106-13 from the National Heart, Lung and Blood Institute and by the American Lung Association. GZR is a recipient of the Harry Shwachman Clinical Investigator Award of the Cystic Fibrosis Foundation. Part of this work was completed during support from a Thomas H. Davis Fellowship of the American Lung Association of North Carolina. ADS is an Edward Livingston Trudeau Scholar. This article was presented in part at the Annual Meeting of the American Thoracic Society, Las Vegas, Nevada, May 1988.

\section{References}

1. James, R., and R. A. Bradshaw. 1984. Polypeptide growth factors. Annu. Rev. Biochem. 53:259-292.

2. D'Ercole, A. J. 1987. Somatomedins/insulin-like growth factors and fetal growth. J. Dev. Physiol. 9:481-495.

3. D'Ercole, A. J., D. B. Foushee, and L. E. Underwood. 1976. Somatomedin-C receptor ontogeny and levels in porcine and human cord serum. J. Clin. Endocrinol. Metab. 43:1069-1077.

4. Barnes, D., and G. Sato. 1980 . Methods for growth of cultured cells in serum-free medium. Anal. Biochem. 102:255-270.

5. Flier, J. S., P. Usher, and A. C. Moses. 1986. Monoclonal antibody to the type I insulin-like growth factor (IGF-I) receptor blocks IGF-I receptor-mediated DNA synthesis: clarification of the mitogenic mechanisms of IGF-I and insulin in human skin fibroblasts. Proc. Natl. Acad. Sci. USA 83:664-668.

6. Van Wyk, J. J., D. C. Graves, S. J. Casella, and S. Jacobs. 1985. Evidence from monoctonal antibody studies that insulin stimulates deoxyribonucleic acid synthesis through the type I somatomedin receptor. J. Clin. Endocrinol. Metab. 61:639-643.

7. King, G. L, C. R. Kahn, M. M. Rechler, and S. P. Nissley. 1980. Direct demonstration of separate receptors for growth and metabolic activities of insulin and multiplication-stimulating activity (an insulinlike growth factor) using antibodies to the insulin receptor. J. Clin. Invest. 66:130140.

8, Kull, F. C., S. Jacobs, Y. Su, M. E. Svoboda, J. J. Van Wyk, and P. Cuatrecasas. 1983. Monoclonal antibodies to receptors for insulin and somatomedin-C. J. Biol. Chem. 258:6561-6566.

9. Van Wyk, J. J., M. E. Svoboda, and L. E. Underwood. 1980. Evidence from radioligand assays that somatomedin-C and insulin-like growth factor-I are similar to each other and different from other somatomedins. J. Clin. Endocrinol. Metab. 50:206-208.

10. Wu, R., and D. Smith. 1982. Continuous multiplication of rabbit tracheal epithelial cells in a defined, hormone-supplemented medium. In Vitro 18:800-812.

11. Van Scott, M. R., J. R. Yankaskas, and R. C. Boucher. 1986. Culture of airway epithelial cells: research techniques. Exp. Lung Res. 11:75-94.

12. Chen, C., and S. C. Chen. 1981. Cell growth factor activity: new quantitative method in cell culture assay. Exp. Cell Res. 136:43-51.

13. Stiles, A. D., B. T. Smith, and M. Post. 1986. Reciprocal autocrine and paracrine regulation of growth of mesenchymal and alveolar epithelial cells from fetal lung. Exp. Lung Res. 11:165-177.

14. Clemmons, D. R., V. K. M. Han, R. C. Elgin, and A. J. D'Ercole, 1987. Alterations in the synthesis of a fibroblast surface-associated $35 \mathrm{~K}$ protein modulates the binding of somatomedin-C/insulin-like growth factor-I. Mol. Endocrinol. 1:339-347.

15. Tollefson, S. E., R. Lajara, R. H. McCusker, D. R. Clemmons, and P. Rotwein. 1989. Insulin-like growth factors (IGF) in muscle development: expression of IGF-I, the IGF-I receptor, and an IGF binding protein daring myoblast differentiation. J.' Biol. Chem. 264:13810-13817.

16. Laemmeli, U. K. 1970. Cleavage of structural proteins during the assembly of the head of bacteriophage T. Nature 227:680-685.

17. Schenborn, E. T., and R. C. Mierendorf, Jr. 1985. A novel transcription property of SP6 and T7 RNA polymerases: dependence on template structure. Nucleic Acids Res. 13:6223-6236.

18. Chirgwin, J. M., A. E. Przybyla, R. J. MacDonald, and W. J. Rutter, 1979. Isolation of biologically active ribonucleic acid from sources enriched in ribonuclease. Biochemistry 18:5294-5299.

19. Aviv, H., and P. Leder. 1972. Purification of biologically active globin gene messenger RNA by chromatography on oligo thymidilic acid cellulose. Proc. Natl. Acad. Sci. USA 69:1408-1412.

20. Thomas, P. S. 1980 . Hybridization of denatured RNA and small DNA fragments transferred to nitrocellulose. Proc. Natl. Acad. Sci. USA 77: 5201-5205.

21. Lund, P. K., B. M. Moats-Staats, M. A. Hynes et al. 1986 . Somatomedin-C insulin-like growth factor-I and insulin-like growth factor-II mRNAs in rat fetal and adult tissues. J. Biol. Chem. 261:14539-14544.

22. Chernausek, S. D., S. Jacobs, and J. J. Van Wyk. 1981. Structural similarities between human receptors for somatomedin $\mathrm{C}$ and insulin: analysis by affinity labeling. Biochemistry 20:7345-7350.

23. Casella, S. J., V. K. M. Han, A. J. D'Ercole, M. E. Svoboda, and J. J. 
Van Wyk. 1986. Insulin-like growth factor II binding to the type I somatomedin receptor: evidence for two high affinity binding sites. $J$. Biol. Chem. 261:9268-9273.

24. Ullrich, A., A. Gray, A. W. Tam et al. 1986. Insulin-like growth factor I receptor primary structure: comparison with insulin receptor suggests structural determinants that define functional specificity. $E M B O J .5$ : 2503-2512.

25. Lowe, W. L., M. Adamo, H. Werner, C. T. Roberts, and D. LeRoith. 1989. Regulation by fasting of rat insulin-like growth factor $I$ and its receptor: effects on gene expression and binding. J. Clin. Invest. 84: 619-626.

26. Van Scott, M. R., N. P. Lee, J. R. Yankaskas, and R. C. Boucher. 1988. Effect of hormones on growth and function of cultured canine tracheal epithelial cells. Am. J. Physiol. 225(Cell Physiol. 24):C237-C245.

27. Zapf, J., H. Walter, and E. R. Froesch. 1981. Radioimmunological determination of insulinlike growth factors I and II in patients with growth disorders and extrapancreatic tumor hypoglycemia. J. Clin. Invest. 69: $1321-1330$.

28. Eigenmann, J. E., D. E. Patterson, and E. R. Froesch. 1984. Body size parallels insulin-like growth factor 1 levels but not growth hormone secretory capacity. Acta Endocrinol. (Copenh.) 106:448-453.

29. Evans, M. J., and S. G. Shami. 1989. Lung cell kinetics. In Lung Cell Biology. D. Massaro, editor. Dekker, New York. 1-36.

30. Snyder, J. M., and A. J. D'Ercole. 1987. Somatomedin C/insulin-like growth factor I production by human fetal lung tissue maintained in vitro. Exp. Lung Res. 13:449-458.

31. D'Ercole, A. J., G. T. Applewhite, and L. E. Underwood. 1980. Evidence that somatomedin is synthesized by multiple tissues in the fetus. Dev. Biol. 75:315-328.

32. Han, V. K. M., A. J. D'Ercole, and P. K. Lund. 1987. Cellular localization of somatomedin (insulin-like growth factor) messenger RNA in the human fetus. Science 236:193-197.

33. Han, V. K. M., D. J. Hill, A. J. Strain et al. 1987. Identification of somatomedin/insulin-like growth factor immunoreactive cells in the human fetus. Pediatr. Res. 22:245-249.

34. Nakanishi, Y., J. L. Mulshine, P. G. Kasprzyk et al. 1988. Insulin-like growth factor I can mediate autocrine proliferation of human small cell lung cancer cell lines in vitro. J. Clin. Invest. 82:354-359. 